\title{
Editorials
}

\section{Le risque allergique des curares}

Marie-Claire Laxenaire MD

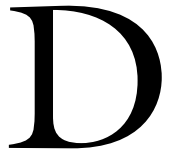

ANS ce numéro du Journal, Baillard et coll., ${ }^{1}$ après avoir été confrontés à deux cas de réaction allergique à un curare dont une mortelle malgré la réanimation correctement menée, ${ }^{2}$ s'interrogent en matière de santé publique sur la justification de cette classe de médicaments en anesthésie. Le débat ouvert ici par Baillard et coll. est intéressant, régulièrement mis à l'ordre du jour depuis des décennies dans les pays où le risque allergique des agents anesthésiques est régulièrement évalué (France, Australie, UK).

La réalité de l'allergie aux curares n'est plus contestée actuellement. ${ }^{3}$ Si dans les années 1970 on considérait que les réactions anaphylactoïdes aux curares étaient expliquées par leur effet pharmacologique et pouvaient être prévenues par des antihistaminiques, ${ }^{4-6}$ on s'est vite aperçu, en pratiquant des investigations allergologiques chez les patients, que la majorité de ces réactions étaient immunologiques, médiées par des IgE spécifiques et qu'il n'existait aucune prémédication efficace. ${ }^{7-11}$

À dater de 1980, la France, comme l'Australie, la Nouvelle Zélande et le Royaume Uni, a développé une intense politique d'investigations allergologiques systématiques chez les patients ayant fait une réaction anaphylactoïde peranesthésique. Il a été créé un réseau national français de centres diagnostiques d'allergoanesthésie, intitulé GERAP («Groupe d'Études des Réactions Anaphylactoïdes Peranesthésiques»), qui travaille de manière coordonnée et suivant la même méthodologie. ${ }^{12}$ Les données sont rassemblées et publiées tous les deux ans, ${ }^{13-18}$ ce qui permet de suivre l'évolution du risque au fil des années. Depuis 20 ans, environ 9000 patients ont été testés par le GERAP. L'origine immunologique, $\mathrm{IgE}$ dépendante, des réactions a été trouvée chez la moitié de ces patients (4 313 cas), l'agent responsable étant avant tout un curare (2944 cas). Dans chacune des six enquêtes du GERAP, la part de responsabilité des curares dans les chocs anaphylactiques est toujours dominante, supérieure à $60 \%$, sans commune mesure avec les hypnotiques $(5 \%)$ ou les morphiniques $(3 \%){ }^{16}$

En Australie, la base de données provient du seul centre diagnostique de Fisher et Baldo, ${ }^{19}$ et concerne des patients venant d'Australie et de Nouvelle Zélande. Les données sont aussi régulièrement publiées mais sous forme cumulée depuis $1974 .^{20}$ Ainsi entre 1974 et 2001 , 1580 patients ont été testés et 750 anaphylaxies ont été diagnostiquées, dues à un curare pour $59 \%$ d'entre elles $(n=441)$; (transmission personnelle de M. Fisher, non publiée). La part de l'anaphylaxie aux curares est donc identique en Australie et en France.

Au Royaume Uni entre 1973 et 1992, il avait été recensé environ 1000 patients dans la structure de recueil centralisée à Sheffield (J. Watkins). ${ }^{21,22}$ Cette structure reçoit les prélèvements sanguins effectués en cours d'accident par les anesthésiologistes. Les résultats des dosages sont analysés à la lumière des dossiers cliniques sans que les patients n'aient bénéficié de tests cutanés d'anaphylaxie. Cette différence d'approche diagnostique rend hasardeuse la comparaison avec les données françaises et australiennes, d'autant que depuis 1992, en l'absence de coordination, les résultats ne sont plus publiés. ${ }^{23}$

Ainsi, les connaissances dans le domaine de l'anaphylaxie en anesthésie reposent avant tout sur les données collectées par les centres diagnostiques français et australien. Il est évident que lorsque ces structures n'existent pas ou qu'il n'y a pas de coordination, il n'y a pas de publications sur le sujet, à l'exception de cas cliniques isolés ou de petites séries ponctuelles. Cela ne veut évidemment pas dire que le risque allergique n'existe que dans les pays qui ont mis en place ces

Du Service d'Anesthésie-Réanimation Chirurgicale, C.H.U. Hôpital Central, Nancy, France.

Adresser la correspondance à: Pr Marie-Claire Laxenaire, Service d'Anesthésie-Réanimation Chirurgicale, C.H.U. Hôpital Central, Case officielle no 34, 29, Avenue du Maréchal de Lattre de Tassigny, 54035 Nancy Cedex, France: Téléphone: 33-03-83-85-14-03; Télécopieur: 33-03-83-85-85-59; Courriel: mc.laxenaire@chu-nancy.fr 
réseaux de surveillance. On ne trouve que ce qu'on recherche et il faut donner aux anesthésiologistes les moyens de faire tester leurs patients aisément et de manière fiable.

L'incidence de l'anaphylaxie aux curares ne peut être évaluée qu'à partir du nombre de cas d'anaphylaxie documentés sur le plan allergologique, rapportés au nombre de patients ayant reçu des curares pendant la même période. Un grand collectif de patients est nécessaire étant donné la rareté de cette complication. Ce calcul d'incidence a été fait en France avec les données de 1996, ${ }^{16}$ année durant laquelle la Société Française d'Anesthésie-Réanimation a réalisé une enquête nationale sur les pratiques de l'anesthésie. ${ }^{24}$ Nous avons ainsi appris qu'environ la moitié des anesthésies générales comportait un curare dans leur protocole, ce qui représentait 2,5 millions de patients exposés annuellement à un curare. La même année, le GERAP avait répertorié 220 cas d'anaphylaxie aux curares ; l'incidence peut alors être chiffrée à l/14 000. En fait, ce chiffre est sûrement sous-estimé puisque nous savons que 30 à $40 \%$ des patients ayant fait une réaction anaphylactoïde ne sont pas testés et qu'il existe d'autres centres diagnostiques en dehors du GERAP qui ne transmettent pas leurs données. ${ }^{16}$ On a considéré que le nombre réel d'anaphylaxies était probablement le double de celui publié par le GERAP, ce qui explique que le chiffre d'incidence ait été extrapolé à 1/6 500. La réalité se situe probablement entre ces deux extrêmes, aux alentours d'une réaction anaphylactique pour 10000 anesthésies comportant un curare.

L'attention avait été attirée au début sur le suxaméthonium, tout au moins en France et au Royaume Uni, jetant un discrédit sur ce curare considéré comme le plus allergisant. En fait, actuellement ce risque est partagé par tous les curares puisque le déterminant allergénique est lié au radical ammonium quaternaire. Il existe une sensibilisation croisée chez la grande majorité des patients porteurs d'IgE spécifiques de ce radical. Comme le suxaméthonium était à l'époque le curare injecté systématiquement pour l'intubation trachéale, il n'était pas étonnant qu'il soit à l'origine de la majorité des cas publiés. Depuis, d'autres curares ont été commercialisés et utilisés pour l'intubation, et on a vu émerger des chocs anaphylactiques à ces nouveaux curares, alors que la fréquence des chocs au suxaméthonium diminuait. ${ }^{15,16}$ Ceci confirme que l'anaphylaxie aux curares est une complication commune à tous les agents de cette classe pharmacologique, avec cependant quelques différences entre eux non rapportées à leurs parts de marché. ${ }^{17,18}$

Connaissant le risque allergique des curares, certes rare $(1 / 10000)$ mais potentiellement mortel, on se doit de tout mettre en œuvre pour l'éviter. La prévention par une prémédication antihistaminique et/ou corticoïde est totalement inefficace en matière d'anaphylaxie, donc constitue une fausse sécurité. Par ailleurs, on ne connait pas de facteurs de risque de sensibilisation aux curares qui pourraient justifier la pratique de tests allergologiques avant une anesthésie, d'autant que la valeur prédictive des tests allergologiques actuels n'a pas été étudiée dans la population en général. ${ }^{12}$ En fait, on ne sait toujours pas comment les patients se sensibilisent aux curares. L'exposition antérieure à ces agents n'apparaît pas comme un facteur obligatoire pour le développement d'une sensibilisation puisque, suivant les séries, 17 à $50 \%$ des patients ont fait une allergie à un curare lors de leur première anesthésie. ${ }^{16,19}$

Puisqu'il n'existe aucune prémédication pour prévenir la réaction et qu'on ne peut prédire les patients qui risquent d'être sensibilisés aux curares (mis à part ceux qui sont déjà connus allergiques à un curare), la seule façon d'éviter une réaction allergique serait de ne pas utiliser de curare ..., ce qui est évidemment irréaliste. Donc, chacun se doit de réfléchir sur la place des curares dans sa pratique anesthésique, en particulier pour l'intubation trachéale. Cette réflexion a été menée par la Société Française d'AnesthésieRéanimation lors de deux conférences de consensus $^{25,26}$ qui ont abouti aux conclusions suivantes : « l'association thiopental-succinylcholine reste le protocole de référence lors de l'induction en séquence rapide " ${ }^{26}$ "l'intubation sans curare peut être proposée lorsque la curarisation n'est pas nécessaire pour la chirurgie», ${ }^{26}$ "l'intubation sans curare est recommandée chez les patients allergiques aux myorelaxants». ${ }^{25}$ Savoir intuber sans curare demande malgré tout un apprentissage car les conditions d'intubation et sa tolérance sont conditionnées par l'association hypnotique-morphinique qu'il faut bien moduler.

L'apprentissage de chaque anesthésiologiste devrait aussi porter sur la prise en charge correcte d'un choc anaphylactique car c'est cela qui conditionne son évolution et la sécurité du patient. Le diagnostic n'est pas toujours facile à faire, surtout si les manifestations cutanées sont manquantes. C'est ainsi que les signes sont parfois attribués à un défaut d'anesthésie ou d'analgésie, à une intubation oesophagienne, un surdosage anesthésique, des interférences médicamenteuses, un choc cardiogénique ... autant d'erreurs diagnostiques à l'origine d'un traitement mal adapté et de séquelles anoxiques définitives. Une illustration de la méconnaissance du choc anaphylactique par les anesthésiologistes a été apportée par une récente étude danoise $:{ }^{27}$ parmi les 42 anesthésiologistes 
seniors confrontés sur simulateur à un choc anaphylactique, aucun n'a fait le diagnostic dans les dix premières minutes et n'a institué le bon traitement, et seulement $25 \%$ l'ont évoqué après $15 \mathrm{~min}$, aidés par l'instructeur. Cela prouve la nécessité d'inclure dans les programmes de formation la prise en charge de ce type de choc et d'afficher dans chaque bloc anesthésique la procédure de diagnostic et de réanimation d'un choc anaphylactique. ${ }^{12}$

\section{Neuromuscular blocking drugs and allergic risk}

In this issue of the Journal, Baillard et al., ${ }^{1}$ after a confrontation with two cases of allergic reactions to a neuromuscular blocking drug (NMBD), one of which proved fatal despite the correct performance of resuscitation maneuvers, ${ }^{2}$ raise the question of whether this class of anesthetic drugs can be justified on public health grounds. The debate opened here by Baillard et $a l$. is an interesting one, and has been regularly on the agenda for decades in countries in which the allergic risk of anesthetic agents is assessed regularly (France, Australia, UK).

The existence of allergies to NMBDs is no longer disputed nowadays. ${ }^{3}$ Although it was thought in the 1970's that anaphylactoid reactions to NMBDs could be explained by their pharmacological effect and that they could be prevented by antihistaminics, ${ }^{4-6}$ allergological investigations on patients quickly showed that most of these reactions were immunological, that they were mediated by specific IgE's and that no effective premedication existed. ${ }^{7-11}$

Starting in 1980, France, like Australia, New Zealand and the United Kingdom, developed an intensive policy of systematic allergological investigations of patients who had had peranesthetic anaphylactoid reactions. A nation-wide French network of allergo-anesthetic diagnostic centres was created, known as GERAP (“Groupe d'Études des Réactions Anaphylactoïdes Peranesthésiques" [Study Group on Peranesthetic Anaphylactoid Reactions]), which does coordinated work and uses the same methodology. ${ }^{12}$ The data are assembled and published every two years, ${ }^{13-18}$ so that risk trends can be followed over the years. Approximately 9,000 patients have been tested by GERAP in 20 years. In half of these patients $(4,313$ cases), the reactions were found to have an immunological, IgE-dependent origin and the main agent responsible was a NMBD $(2,944$ cases $)$. In each of the six GERAP investigations, NMBDs always played a dominant role, over $60 \%$, in the anaphylactic shocks, which can't be compared with hypnotics $(5 \%)$ or morphinics $(3 \%) .{ }^{16}$

In Australia, the data base is derived solely from the Fisher and Baldo diagnostic centre, ${ }^{19}$ and involves patients from Australia and New Zealand. The data are also regularly published, but this has been done in cumulative form since $1974 .{ }^{20}$ Thus from 1974 to $2001,1,580$ patients were tested and 750 anaphylactic reactions were diagnosed, $59 \%$ of which were due to a NMBD ( $n=441)$; (unpublished data; M. Fisher, personal communication). The proportion of anaphylactic cases related to the use of NMBDs is thus identical in Australia and France.

In the United Kingdom, approximately 1,000 patients were identified by the centralized collection system based in Sheffield between 1973 and 1992 (J. Watkins). ${ }^{21,22}$ This system receives blood specimens collected by anesthesiologists during the reactions. The assay results are analyzed in the light of the clinical files without the patients having been given anaphylactic skin tests. This different diagnostic approach makes a comparison with French and Australian data risky, especially as, because of the lack of coordination, the results have not been published since 1992. ${ }^{23}$

Thus, our knowledge of anaphylaxis during anesthesia is mainly based on data collected by French and Australian diagnostic centres. It is clear that, when these systems do not exist or there is no coordination, nothing is published on the subject except for isolated clinical cases or short series of cases over limited periods. This obviously does not mean that the risk of allergies only exists in countries which have established these monitoring networks. We can only find something if we look for it and anesthesiologists must be given the means to test their patients easily and reliably.

The incidence of NMBD anaphylaxis can only be assessed by calculating the number of anaphylactic cases documented allergologically, compared to the number of patients given NMBDs during the same period. Because this complication is rare, a large patient group is needed. The incidence has been calculated in France, using data from $1996,{ }^{16}$ the year when the Société Française d'Anesthésie-Réanimation [the French Anesthesiologists' Society] carried out a nation-wide investigation of anesthesia practices. ${ }^{24} \mathrm{We}$ thus found out that a NMBD is included in the protocol of approximately half of general anesthesias, 
which means that 2,5 million patients are exposed to a NMBD annually. The same year, GERAP identified 220 cases of NMBD anaphylaxis; the incidence therefore amounts to $1: 14,000$. In fact, this figure is certainly an underestimation, as we know that $30 \%$ to $40 \%$ of the patients who have anaphylactoid reactions are not tested and there are other diagnostic centres apart from GERAP, which do not forward their data. ${ }^{16}$ It is thought that the actual number of anaphylactic cases is probably twice the number published by GERAP, which explains why the incidence figure has been extrapolated to $1: 6,500$. The true situation is probably between these two extremes, with approximately one anaphylactic reaction for every 10,000 anesthesias using a NMBD.

Attention centered on suxamethonium to start with, at least in France and the United Kingdom, thus discrediting this NMBD, which is considered the most allergizing. In fact all NMBDs share responsibility for the risk, as the allergenic determinant is linked to the quaternary ammonium radical. The vast majority of patients who are carriers of the specific IgE's of this radical show crossed sensitization. As suxamethonium was used systematically for endotracheal intubation at the time, it is not surprising that it was behind most of the published cases. Other NMBDs have been marketed and used for intubation since then and anaphylactic shocks have appeared with the use of these new drugs, whereas the frequency of shock from suxamethonium has decreased. ${ }^{15,16}$ This confirms that anaphylaxis is a complication common to all the agents in this pharmacological class, although there are a few differences between them which are not in proportion to their market shares. ${ }^{17,18}$

As we are aware of the allergic risk of NMBDs, which is admittedly rare $(1: 10,000)$ but potentially fatal, we must do our utmost to avoid it. Antihistaminic and/or corticoid premedication is totally ineffective in preventing anaphylaxis and therefore only offers a feeling of false safety. In addition, we do not know of any risk factors for sensitization to NMBDs which could justify administering allergological tests prior to anesthesia, especially as the predictive value of current allergological tests has not been studied in the general population. ${ }^{12}$ In fact, we still do not know how patients become sensitized. Prior exposure to these agents does not seem to be necessary, as, according to the series, $17 \%$ to $50 \%$ of patients developed an allergy to a NMBD the first time they were anesthetized. ${ }^{16,19}$

As there is no premedication which can prevent the reaction, and as we cannot predict which patients risk being sensitized (apart from those who are already known to be allergic to a NMBD), the only way to avoid an allergic reaction would be to avoid using a NMBD..., which is obviously unrealistic. So everyone of us must think about the role played by NMBDs in his or her anesthetic practice, especially during tracheal intubation. This topic was considered at two consensus conferences held by the Société Française d'Anesthésie-Réanimation ${ }^{25,26}$ which came to the following conclusions: "a thiopental/succinylcholine combination remains the reference protocol for rapid sequence induction", 26 "intubation without the use of a NMBD can be suggested when a NMBD is not required for the surgery", 26 "intubation without a NMBD is recommended for patients who are allergic to muscle relaxants". ${ }^{25}$ However, it is necessary to learn how to intubate without NMBDs, as intubation conditions and tolerance to intubation are conditioned by the hypnotic/opioid association, which has to be adjusted properly.

Every anesthesiologist must also learn proper case management in the event of an anaphylactic shock, as this is what determines the patient's evolution and safety. The condition is not always easy to diagnose, especially if there are no skin manifestations. Thus the signs are sometimes attributed to defective anesthesia or analgesia, an esophageal intubation, an overdose of anesthetic, drug interferences, a cardiogenic shock... all diagnostic errors which result in a poorly adapted treatment and lasting anoxic after-effects. An illustration of the failure of anesthesiologists to recognize anaphylactic shock was reported in a recent Danish study: ${ }^{27}$ out of 42 senior anesthesiologists confronted with an anaphylactic shock on a simulator, not one adopted this diagnosis or initiated the proper treatment during the first ten minutes and only $25 \%$ adopted the diagnosis after $15 \mathrm{~min}$, when prompted by the instructor. This proves that we must include case management of this type of shock in training programs and shows that every anesthesiology department should post the procedure for diagnosing and resuscitating patients suffering from anaphylactic shock. ${ }^{12}$

\section{Références}

1 Baillard C, Larmignat P, Fournier JL, Denantes C, Cupa M, Samama CM. Anesthesia: with or without curare? (Letter) Can J Anesth 2003; 50: 522.

2 Baillard C, Korinek AM, Galanton V, et al. Anaphylaxis to rocuronium. Br J Anaesth 2002: 88: 600-2.

3 Laxenaire $M C$. Quelle est la réalité du risque allergique en anesthésie ? Incidence. Aspects cliniques. Morbiditémortalité. Substances responsables. Ann Fr Anesth Réanim 2002; 21 (Suppl 1): 38-54.

4 Comroe JH, Dripps RD. The histamine-like reaction of 
curare and tubocurarine injected intracutaneously and intraarterialy in man. Anesthesiology 1946; 7: 260-2.

5 Bele-Binda N, Valerie F. A case of bronchospasm induced by succinylcholine. Can Anaesth Soc J 1971; 18: 116-7.

6 Moss J, Philbin DM, Rosow CE, Basta SJ, Gelb C, Savarese JJ. Histamine release by neuromuscular blocking agents in man. Klin Wochenschr 1982; 60: 891-5.

7 Jerums G, Whittingham S, Wilson P. Anaphylaxis to suxamethonium. A case report. Br J Anaesth 1967; 39: 73-6.

8 Katz AM, Mulligan PG. Bronchospasm induced by suxamethonium. A case report. Br J Anaesth 1972; 44: 1097-8.

9 Mandappa JM, Chandrasekhara PM, Nelvigi RG. Anaphylaxis to suxamethonium. Two case reports. Br J Anaesth 1975; 47: 523-5.

10 Fisher MM. Intradermal testing in the diagnosis of acute anaphylaxis during anaesthesia - results of five years experience. Anaesth Intensive Care 1979; 7: 58-61.

11 Moneret-Vautrin DA, Laxenaire MC, Moeller $R$. Anaphylaxis due to succinylcholine.

Immunoallergological study of thirteen cases. Clin Allergy 1981; 11: 175-83.

12 Société Française d'Anesthésie et de Réanimation. Prévention du risque allergique peranesthésique. Recommandations pour la Pratique Clinique 2001. www.sfar.org/allergierpc.html.

Reducing the risk of anaphylaxis during anaesthesia (English). Ann Fr Anesth Réanim 2002; 21 (suppl 1): 7-23.

13 Laxenaire MC, Moneret-Vautrin DA, Widmer S, Mouton C, Guéant JL. Substances anesthésiques responsables de chocs anaphylactiques. Enquête multicentrique française. Ann Fr Anesth Réanim 1990; 9: 501-6.

14 Laxenaire $M C$. Drugs and other agents involved in anaphylactic shock occurring during anaesthesia. A French multicenter epidemiological inquiry. Ann Fr Anesth Réanim 1993; 12: 91-6.

15 Laxenaire MC, et le Groupe d'étude des réactions anaphylactoïdes peranesthésiques. Substances responsables des chocs anaphylactiques peranesthésiques. Troisième enquête multicentrique française (1992-1994). Ann Fr Anesth Réanim 1996; 15: 1211-8.

16 Laxenaire $M C$, et le Groupe d'étude des réactions anaphylactoïdes peranesthésiques. Quatrième enquête multicentrique (juillet 1994-décembre 1996). Ann Fr Anesth Réanim 1999; 18: 796-809.

17 Laxenaire MC, Mertes PM and Groupe d'étude des réactions anaphylactoïdes peranesthésiques. Anaphylaxis during anaesthesia. Results of a two-year survey in France (1997-1998). Br J Anaesth 2001; 87: 549-58.
18 Mertes PM, Laxenaire MC, and Groupe d'étude des réactions anaphylactoïdes peranesthésiques. Anaphylaxis during anesthesia. Results of a two-year survey in France (1999-2000). Anesthesiology 2002; 96: A1083 (abstract).

19 Fisher M, Baldo BA. Anaphylaxis during anaesthesia: current aspects of diagnosis and prevention. Eur J Anaesthesiol 1994; 11: 263-84.

20 Whittington T, Fisher MM. Anaphylactic and anaphylactoid reactions. Baillière's Clinical Anaesthesiology 1998; 12: 301-23.

21 Watkins J. Adverse anaesthetic reactions. An update from a proposed national reporting and advisory service. Anaesthesia 1985; 40: 797-800.

22 Watkins J. Second report from an anaesthetic reactions advisory service (Letter). Anaesthesia 1989; 44: 157-9.

23 Watkins J, Wild G, Ward AM. A case for co-ordinated investigation and reporting of hypersensitivity-type drug reactions in the UK. Anaesthesia 2000; 55: 1127-8.

24 Laxenaire MC, Auroy $\Upsilon$, Clergue F, Pequignot F, Jougla $E$, Lienhart $A$. Organisation et techniques de l'anesthésie. L'anesthésie en France en 1996. Ann Fr Anesth Réanim 1998; 17: 1317-23.

25 Société Française d'Anesthésie et de Réanimation. Indications de la curarisation en anesthésie. Conférence de consensus. www.sfar.org, 1999.

26 Société Française d'Anesthésie-Réanimation en collaboration avec la Société française d'oto-rhino-laryngologie. Prise en charge des voies aériennes en anesthésie adulte à l'exception de l'intubation difficile. Conférence de consensus. www.sfar.org, 2002.

27 Jacobsen J, Lindekaer AL, Ostergaard HT, et al. Management of anaphylactic shock evaluated using a full-scale anaesthesia simulator. Acta Anaesthesiol Scand 2001; 45: 315-9. 